[12] Dorohovich, V. V., Lazarenko, N. P. (2008). Doslidshenniia teplomasoobminnykh protsesiv, shcho vidbuvayut'sya pry vypikanni keksu na laktytoli. Khlibopekar i kondyter, 9, 21-23.

[13] Snyezhkin, Yu. F., Mykhaylyk, V. A., Dmytrenko, N. V. (2011). Dynamika zminy stanu vody v parenkhimnykh tkanynakh roslyn pry sushinni. Promyshlennaya teplotekhnyka, 33 (2), 35-40.

[14] Potapov, V. A. (2009). Kynetyka sushky: analyz y upravlenye protsessom. Kharkiv: KhGUPT, 250.

\title{
THE STUDY OF THE METHOD OF FIGHT AGAINST FORMATION OF POLARIZING LAYER AT THE PROCESS OF ULTRAFILTRATION CONCENTRATION OF THE SKIM MILK
}

\author{
Gregoriy Deynichenko \\ Department of Equipment Food and Hospitality Industry them. Belaeva \\ Kharkiv State University of Food Technology and Trade \\ 333 Klochkovskaya str., Kharkiv, Ukraine, 61051 \\ DeynichenkoGV@rambler.ru \\ Vasyl Guzenko \\ Department of Equipment Food and Hospitality Industry them. Belaeva \\ Kharkiv State University of Food Technology and Trade \\ 333 Klochkovskaya str., Kharkiv, Ukraine, 61051 \\ Peresada_7@mail.ru \\ Oleg Udovenko \\ PhD, Associate Professor \\ Department of General Engineering Disciplines and Equipment
}

Donetsk National University of Economics and Trade named after Mykhailo Tugan-Baranovsky 16 Ostrowski str., Kryvyi Rih, Ukraine, 50005

Udoleg@mail.ru

Aleksandr Omelchenko

PhD, Associate Professor

Department of General Engineering Disciplines and Equipment

Donetsk National University of Economics and Trade named after Mykhailo Tugan-Baranovsky

16 Ostrowski str., Kryvyi Rih, Ukraine, 50005

omelchenko84@ukr.net

Olga Melnik

PhD, Associate Professor

Department of General Engineering Disciplines and Equipment

Donetsk National University of Economics and Trade named after Mykhailo Tugan-Baranovsky

16 Ostrowski str., Kryvyi Rih, Ukraine, 50005

melnikolgaevgenivna@ukr.net

\footnotetext{
Abstract

The description of experimental set and the method of processing of the results of the study of the method of fight against formation of polarizing layer in the process of ultrafiltration concentration of skim milk raw material were presented. The results of experimental studies relative to the sparging method application for the prevention of polarizing layer in the process of membrane processing of the skim milk and its influence on the capacity of ultrafiltration membranes were offered. The mathematical models were constructed on the base of regressive equations of factorial experiment using the method of the raw material sparging above the membrane surface for selection of technological parameters of the process of ultrafiltration concentration of the skim milk. The ra-
} 
tional working parameters of the process of ultrafiltration concentration of the skim milk using the sparging of the skim milk by the gas bubbles in the direct closeness to the membrane surface were determined. Such working parameters are: pressure - 0,4 ...0,5 MPa, temperature of skim milk $-40 \ldots 50^{\circ} \mathrm{C}$, frequency of sparging of skim milk $-0,10 \ldots 0,15 \mathrm{~min}^{-1}$, pressure of sparging must be $0,56 \ldots 0,58 \mathrm{MPa}$.

Keywords: skim milk, membrane processing, polarizing layer, ultrafiltration concentration, sparging.

\section{Introduction}

The aim of the work is the study of sparging method application for prevention of formation of polarizing layer on the membrane surface at the process of UF-concentration of the skim milk.

To attain the set aim it is necessary to solve the following tasks:

- to characterize the modern state of prevention of polarizing layer formation on membrane surface;

- to determine factors that influence the process of UF-concentration of the skim milk using the sparging method;

- to determine the rational parameters of ultrafiltration concentration of the skim milk on the base of the results of research.

Among all known membrane processes (microfiltration, ultrafiltration, nanofiltration, reverse osmose and so on) [1] the ultrafiltration is most suitable for the processing of skim milk raw material, because the ultrafiltration process is characterized with such advantages as the high economy, low energy capacity, absence of phase transformations of protein [2]. As opposite to the reverse osmose and nanofiltration the ultrafiltration process runs at lower pressure $(0,2 \ldots 0,6 \mathrm{MPa})$ and at the same time provides much higher selectivity than microfiltration [3]. Together with concentration of food solutions UF realizes their cleansing from the low-molecular substances, bacteria, keeping the constant $\mathrm{pH}$ value. All aforesaid conditions the wide use of ultrafiltration process at the milk raw material processing at its application in the technologies of milk products [4].

Despite the fact that the processes of membrane processing are successfully used in food industry at the production of milk and milk products, today the technical support of ultrafiltration for the skim milk processing has a series of complications [5].

The modern development of membrane technologies allows create the series of membranes of new generation that conditions the wider field of their use in food industry. That in its turn needs creation of the new technical support, including in the conditions of the skim milk processing [6].

The restraining role in the development of ultrafiltration methods of processing of the skim milk raw material is played by the low specific output of UF-membranes, caused by the peculiar properties of high-molecular substances of the skim milk raw material [7]. At the same time throughout the world is observed the practical absence of improved ultrafiltration sets of the low capacity that is explained by insufficient number of experimental data relative to the working characteristics of new membranes, necessary for the calculation of process of UF-concentration of the milk raw material and equipment for its realization [8].

The wide introduction of sparging processes is impeded by the lowering of membranes permeability in the process of separation, which main cause is the formation of the sediment layer on the membrane surface that is concentration polarization [9]. For prevention of polarizing layer formation it is necessary to provide in construction of created membrane module the device that turbulizes the flow of separated polydisperse system [10].

Hydromechanical methods are more suitable in the aspect of preservation of the native properties and components of separated raw material among all ways of active impact on the process of formation of concentration polarization layer [11]. One can become acquainted more detail with the ways and devices of hydromechanical prevention of formation of polarizing layer on membrane surfaces from the work [12]. Among the existent method it seems to be prospective to use the process of sparging of the flow of separated system for its additional turbulization that is the aim of this research. 


\section{Materials and Methods}

For acceleration of the process of UF-concentration of the skim milk was offered the method of the fight against polarizing layer by the sparging of processed food liquids by the babbles of air or inert gas in direct closeness to the surface of semi-permeable UF-membranes. At that the acceleration of ultrafiltration process takes place at the expanse of combined influence on gel, formed on the membrane surface, sparging pressure, turbulization of the flows of processed liquid and hydraulic impact of liquid on the UF-membrane surface.

\section{1. Experimental procedures}

On the Fig. 1 is presented the principal scheme of ultrafiltration laboratory set on the base of membrane module with sparging device.

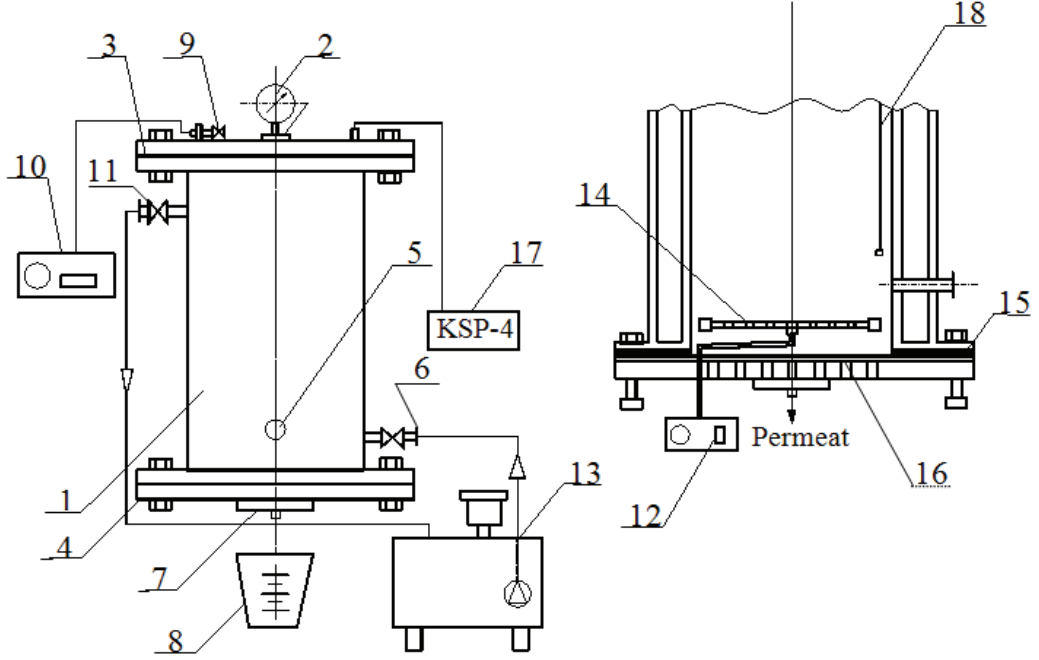

Fig. 1. The principal scheme of ultrafiltration laboratory set on the base of membrane module with sparging device: 1 - body of filtrating module; 2 - manometer; 3 - top cover; 4 - low cover;

5 - cock for removal of ultrafiltration concentrate; 6 - nipple of input of intermediate coolant; 7 - connection for permeate removal; 8 - container for permeate collection; 9 - cock for input of pressure and depressurization; 10 - compressor for pumping of pressure; 11 - nipple of output of intermediate coolant; 12 - compressor for sparging; 13 - ultrathermostat; 14 - sparging device;

15 - rubber gasket; 16 - semi-permeable membrane; 17 - potentiometer KSP-4

(ST "Lviv device", Ukraine); 18 - thermocouple

The base of ultrafiltration laboratory set is a filtrating module 1, made of stainless steel, which internal volume is 51 . The flanges are welded to the top and low bases of modules, the top 3 and low 4 covers are fixed to these flanges by clamping bolts. Hermeticity of coats fixation is provided by the rubber gaskets 15 . On the low cover with through radially drilled orifices for permeate removal is fixed the semi-permeable ultrafiltration membrane 16. Manometer 2 is embedded in the top cover for the control of pressure of the process that provides the supporting of necessary pressure of filtration at full hermeticity, and thermocouple 18, connected with potentiometer $17 \mathrm{KSP}-4$. On the top cover is also placed the cock for input of pressure and depressurization 9, through which the necessary pressure is formed in the module using compressor 10.

In the middle of working chamber of module in parallel to surface of semi-permeable membrane is placed the sparging device (bubbler) 14, made as torus with orifices, connected to the compressor for sparging 12. Filtrating module is equipped with water jacket, which temperature is regulated using ultrathermostat UT-15 (Odessa experimental plant of laboratory medical technique, Ukraine) 13 through the nipples of input 6 and output 11 of coolant. In the low part of filtrating module is placed the cock for removal of ultrafiltration concentrate of separated raw material 5. 
Permeate is removed from the module using the connection 7 and collected in container 8 . The summary working surface of membranes in device is $0,024 \mathrm{~m}^{2}$.

The appearance of ultrafiltration device in the process of concentration of the skim milk in laboratory conditions in presented on the Fig. 2.

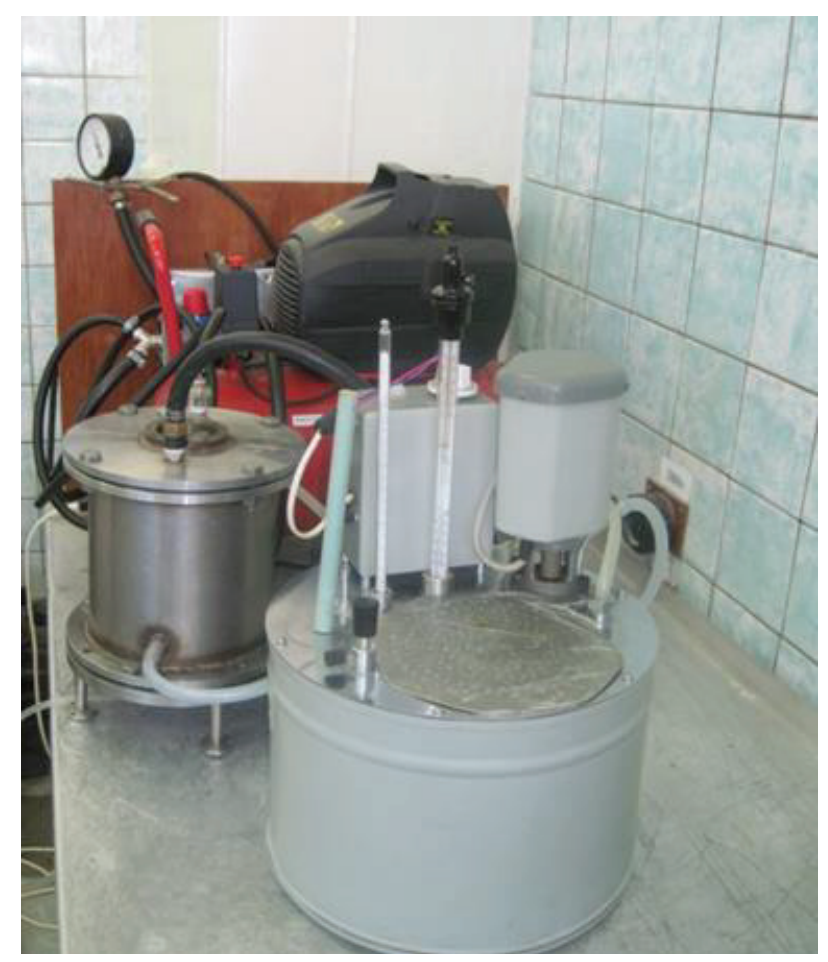

Fig. 2. Appearance of laboratory set

The ultrafiltration process in this ultrafiltration laboratory set is realized as following. The working chamber of filtrating membrane module is filled with separated raw material, the necessary pressure is created using compressor, and the ultrafiltration is carried out. For the study of influence of sparging on the process of infiltration separation of the food liquid, the sparging compressor is switched on and creates turbulization of system near the surface of semi-permeable membrane through the sparging device. In the process of ultrafiltration permeate passes through the membrane pores, it is removed from filtrating module using connection and collected in container. Ultrafiltration concentrate of separated liquid is taken from filtering module by cock after attaining the necessary value of concentration factor.

\section{2. The modeling of process of UF-concentration of the skim milk}

For determination of characteristics of the process of UF-filtration of the skim milk, the mathematical model by the method of experiment planning was offered. The regression equations $(1,2)$, received as the result of modeling of changed parameters of UF-concentration of the skim milk, favor the more detail study of phenomena that take place at ultrafiltration of the skim milk raw material. At the same time they determine the optimal conditions of UF-concentration of the skim milk to receive concentrates with the different value of UF-membranes capacity on the base of copolymers of acrylonitrile (PAN), presented below [13].

The membrane capacity at UF-concentration of the skim milk in ordinary mode:

$$
\begin{gathered}
\mathrm{G}_{\mathrm{m}}=-5,161+0,096 \mathrm{t}+42,85 \mathrm{P}-0,194 \tau- \\
-1,423 \cdot 10^{-4} \mathrm{t}^{2}-51,096 \mathrm{P}^{2}-2,431 \cdot 10^{-3} \tau^{2}- \\
-0,015 \mathrm{t} \cdot \mathrm{P}-8,266 \cdot 10^{-3} \mathrm{t} \cdot \tau-0,124 \mathrm{P} \cdot \tau .
\end{gathered}
$$


The membrane capacity at UF-concentration of the skim milk using the sparging method:

$$
\begin{gathered}
\mathrm{G}_{\mathrm{m}}=-168,099-6,431 \cdot 10^{-3} \mathrm{t}+31,366 \mathrm{P}+ \\
+587,479 \mathrm{P}_{1}+27,009 \mathrm{n}_{\mathrm{s}}+2,133 \cdot 10^{-5} \mathrm{t}^{2}- \\
-29,407 \mathrm{P}^{2}-516,667 \mathrm{P}_{1}{ }^{2}-18,596 \mathrm{n}^{2}-0,014 \mathrm{t} \cdot \mathrm{P}+ \\
+0,078 \mathrm{t} \cdot \mathrm{P}_{1}-0,028 \mathrm{t} \cdot \mathrm{n}-2,508 \cdot \mathrm{P} \cdot \mathrm{P}_{1}+4,749 \cdot \mathrm{P} \cdot \mathrm{n}-32,193 \cdot \mathrm{P}_{1} \cdot \mathrm{n} .
\end{gathered}
$$

At that for the study of the process of UF-concentration of the skim milk were chosen the following main input parameters of process: $\mathrm{t}$ - temperature of UF-concentration, ${ }^{\circ} \mathrm{C} ; \mathrm{P}$ - pressure of filtration, $\mathrm{MPa} ; \mathrm{n}_{\mathrm{s}}$ - frequency of sparging, $\mathrm{min}^{-1} ; \mathrm{P}_{1}$ - pressure of sparging, MPa.

For the study was used the skim milk, produced at enterprise LTD "MOLAGRO PLUS", city Lozovaya, Kharkiv region, Ukraine with the following chemical composition: dry substances $-8,5 \%$; protein 3,2\%; fat-0,07\%).

\section{Results}

The important factor that essentially influences the process of UF-concentration of the skim milk using the method of sparging of initial raw material above the membrane surface is a frequency of sparging $\left(n_{s}\right)$.That is why there was studied the influence of sparging frequency on the capacity of studied UF-membranes of separated skim milk at the temperature $20{ }^{\circ} \mathrm{C}$ and pressure of UF-concentration process 0,4 MPa [14], presented on the Fig. 3.

On the Fig. 3 can be seen that the intensive increase of capacity of both membranes takes place at the increase of sparging frequency to the values $0,10 \ldots 0,15 \mathrm{~min}^{-1}$, after that the capacity parameters at UF-concentration of the skim milk are stabilized.

Besides the sparging frequency of separated raw material, the creation of hydrodynamic conditions near the surfaces of semi-permeable UF-membranes is also influenced by the sparging pressure $\left(\mathrm{P}_{1}\right)$. That is why at the next stage the influence of sparging pressure on the capacity of membranes of PAN type was studied. The results of the study are presented on the Fig. $\mathbf{4}$.

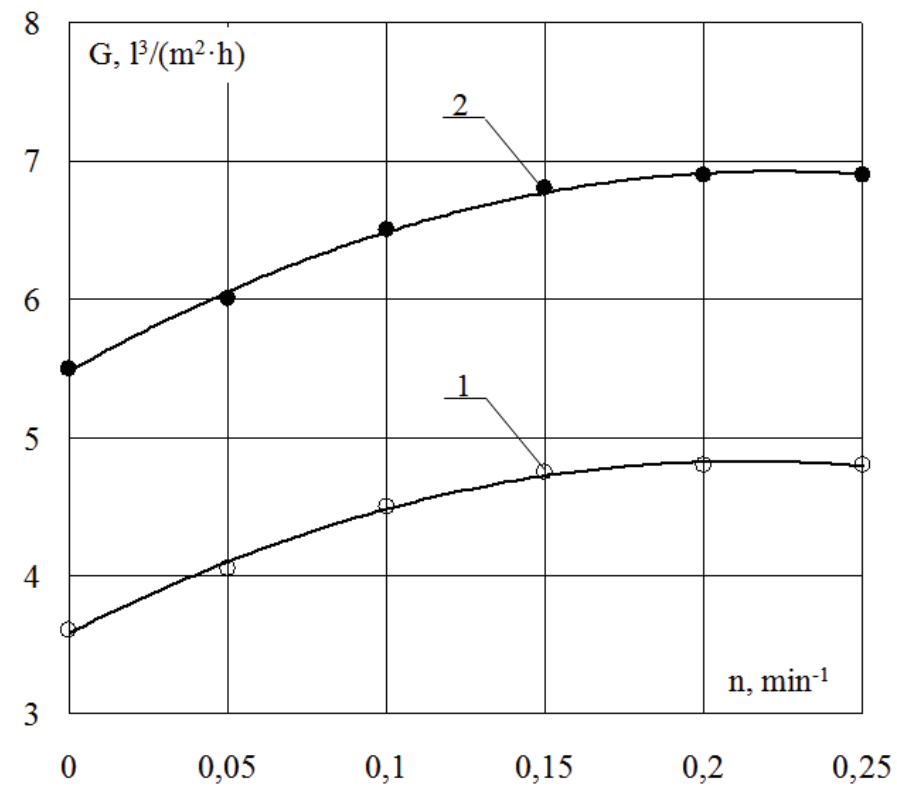

Fig. 3. The dependence of capacity $(G)$ of UF-membranes on the sparging frequency $\left(\mathrm{n}_{\mathrm{s}}\right)$ of processed raw material at UF-concentration of the skim milk (temperature $20^{\circ} \mathrm{C}$, filtration pressure 0,4 $\mathrm{MPa}$ and sparging pressure 0,46 $\mathrm{MPa}$ ): 1 -membrane PAN-50; 2 - membrane PAN-100

The data of Fig. 4 demonstrate that the sparging pressure influence the ultrafiltration process significantly less than the sparging frequency. At the raise of the sparging pressure 
values the capacity of UF-membranes of PAN type droningly increases and this dependency has the linear character.

The rational interval of sparging pressure is the values $0,56 \ldots 0,58 \mathrm{MPa}$, because they mostly favor the raise of capacity of ultrafiltration membranes of PAN type but the critical value of pressure in UF-module is not attained at that.

As the result of mathematical modeling the conditions of UF-concentration process using ultrafiltration membranes of PAN type (PAN-50 and PAN-100) were determined. It allowed determine the rational parameters of capacity and also the possible values of this characteristic under conditions of optimal parameters of the process.

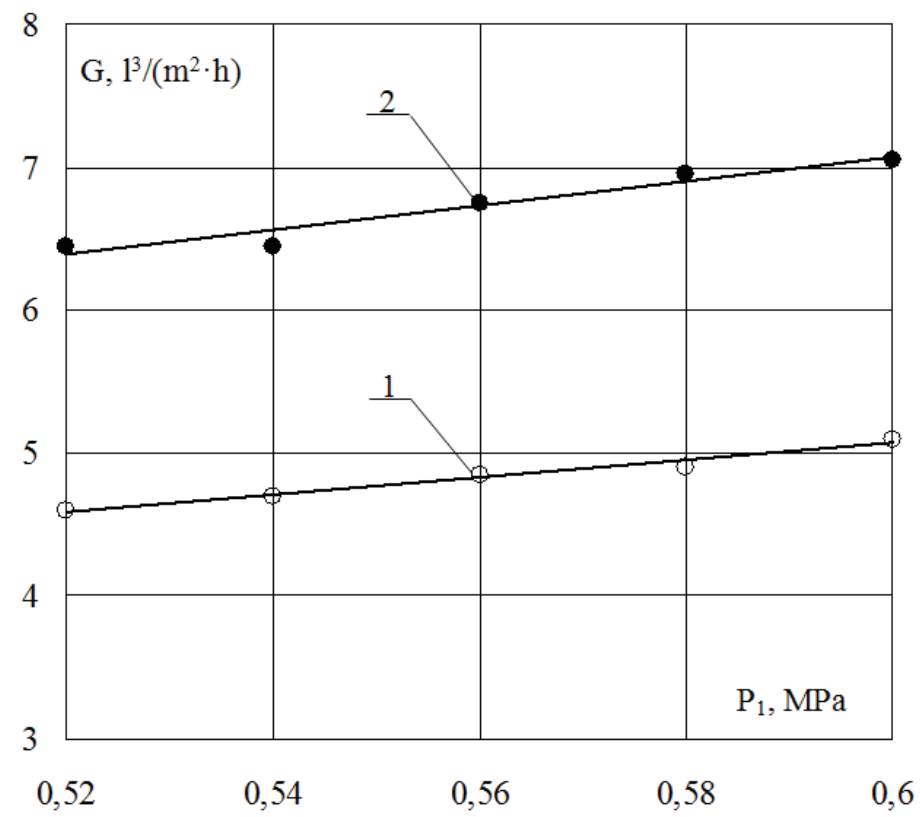

Fig. 4. The dependence of capacity $(\mathrm{G})$ of UF-membranes on the sparging pressure $\left(\mathrm{P}_{1}\right)$ at membrane separation of the skim milk at temperature $20{ }^{\circ} \mathrm{C}$, filtration pressure $0,4 \mathrm{MPa}$ and sparging frequency $0,15 \mathrm{~min}^{-1}: 1$ - membrane PAN-50; 2 - membrane PAN-100

Optimization of technological modes of UF of the skim milk in blind mode and using the method of fight against polarizing layer allowed construct the three-dimensional graph dependencies, characterizing the aforesaid processes (Fig. 5). The most rational modes of UF-concentration processes are marked on the graph dependencies by the special hatching.

Experimental studies of technological modes using mathematical model allowed choose the rational technological parameters of UF-concentration of the skim milk in ordinary mode and using sparging near the surface of UF-membranes of PAN type. The maximal effectiveness of the process of UF-concentration of the skim milk in ordinary mode and also using the sparging of raw material is attained at the values of filtration pressure - $0,4 \ldots 0,5 \mathrm{MPa}$, temperature of UF-processing of initial raw material $-40 \ldots 50^{\circ} \mathrm{C}$.

The comparative analysis of calculated and experimental characteristics of received UF-concentrates demonstrated the similarity of calculated and experimental data on the capacity of two types of membranes.

The analysis of the data of mathematical modeling testifies that with the raise of temperature from $20{ }^{\circ} \mathrm{C}$ to $40 \ldots 50{ }^{\circ} \mathrm{C}$ takes place the increase of the speed of permeate movement in $1,29 \ldots 1,32$ times at UF-concentration of the skim milk at the expense of decrease of its viscosity. At further raise of the temperature the speed of UF-concentration almost does not change that can be explained by the hidden coagulation of protein, due to which it settles on the surface of semi-permeable membranes, firming the polarizing layer [15]. 


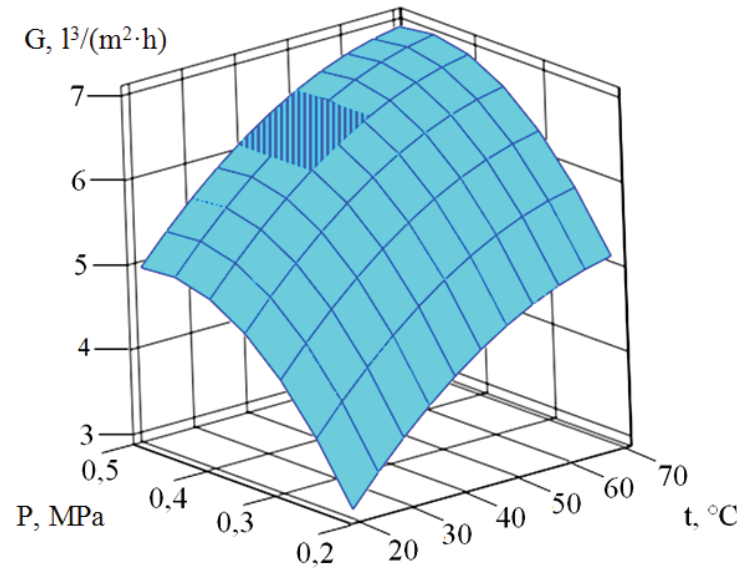

a



$b$

Fig. 5. Mathematical model of selection of technological parameters of semi-permeable membranes of PAN type at UF-concentration of the skim milk: $a$ - ordinary mode; $b$ - using the sparging method at sparging frequency $\mathrm{n}_{2}=0,15 \mathrm{~min}^{-1}$, sparging pressure $\mathrm{P}_{1}=0,58 \mathrm{MPa}$

At increase of UF process pressure we can observe that the capacity of PAN UF-membranes intensively increases to the pressure values $0,3 \ldots 0,4 \mathrm{MPa}$ for the ordinary mode and $0,4 \ldots 0,5 \mathrm{MPa}$ using the method of sparging of initial raw material, after that the speed of its increase is slowed down. Obviously, it is explained by the growth of hydraulic resistance of sediment that was formed on the surface of UF-membrane [16].

The analysis of received regression equations of mathematical model demonstrated that the capacity values of UF-membranes of PAN type depend on pressure, duration, temperature, frequency and pressure of sparging. But UF-membranes capacity increase most of all with the raise of temperature of the process of UF-concentration of the skim milk at the high working pressure and sparging pressure.

Along with it UF-membranes capacity in the process of ultrafiltration of the skim milk is also essentially influenced by the pair impact of temperature and duration of process; temperature of the raw material and working pressure; sparging pressure and temperature of processed environment; working pressure and frequency of sparging.

\section{Conclusions}

1. The information about the fact that for today the hydraulic methods are prospective for the fighting against polarizing layer in the aspect of improvement of the process of ultrafiltration of the skim milk is gained. At the same time the question about creation of new methods of prevention of polarizing layer on the surface of semi-permeable membrane that would favor the increase of membrane equipment capacity remains topical.

2. The essential influence of sparging method on the formation of polarizing layer on the surface of ultrafiltration membrane was experimentally proved.

3. The received results allowed determine the rational parameters of the process of ultrafiltration concentration of the skim milk using UF-membranes of PAN type and using sparging method: pressure $-0,4 \ldots 0,5 \mathrm{MPa}$, temperature of skim milk $-40 \ldots 50{ }^{\circ} \mathrm{C}$, sparging frequency of skim milk $-0,10 \ldots 0,15 \mathrm{~min}^{-1}$, sparging pressure must be $0,56 \ldots 0,58 \mathrm{MPa}$.

4. It was established, that in the sparging mode takes place intensification of the process of UF-concentration of the skim milk in 1,3...1,4 times comparing with UF in blind mode. But this phenomenon leads only to the partial elimination of polarizing layer from the membrane surface. The result is the firming of remained layer on the membrane surface with the increase of UF process duration that nonetheless leads to the significant decrease of membrane capacity. 
5. These studies are the continuation of the studies on the improvement of processes of membrane processing of food high-molecular liquids using the new types of membrane elements and on elaboration of the methods of fight against polarizing layer on their surface.

6. The received results can be used at the study of other technical parameters in the process of UF-concentration of the skim milk products and also for the improvement of instrument equipment of manufacturing lines for the milk raw material processing.

\section{References}

[1] Marella, Ch., Muthukumarappan, K., Metzger, L. E. (2013) Application of Membrane Separation Technology for Developing Novel Dairy Food Ingredients. Journal of Food Process Technol, 4 (9), 294-302. doi: 10.4172/2157-7110.1000269

[2] Hu, K., Dickson, J. M. (2015). Membrane Processing for Dairy Ingredient Separation. Oxford: Wiley Blackwell, 269. doi: 10.1002/9781118590331

[3] Kelly, P. (2011). Milk Protein Concentrate. Encyclopedia of Dairy Sciences, 2, 848-854. doi: 10.1016/B978-0-12-374407-4.00346-0

[4] Berk, Z. (2009). Food process Engineering and Technology. USA: Elsevier, 605. doi: 10.1016/ B978-0-12-373660-4.00001-6

[5] Li, Y., Corredig, M. (2014). Calcium release from milk concentrated by ultrafiltration and diafiltration. Journal of dairy science, 97 (9), 5294-5302. doi: 10.3168/jds.2013-7567

[6] Membrane Filtration in the Dairy Industry. GEA engineering for a better world. Available at: http://www.gea.com/en/binaries/Membrane\%20Filtration\%20in\%20the\%20Dairy\%20Industry_tcm1118227.pdf (Last accessed: 06.10.2016).

[7] Gomaa, H. G., Rao, S. (2011). Analysis of flux enhancement at oscillating flat surface membranes. Journal of Membrane Science, 374 (1-2), 59-66. doi: 10.1016/j.memsci.2011.03.011

[8] Bogomolov, V., Lazarev, S. (2014). Promyshlennaja pererabotka vtorichnogo molochnogo syr’ja. Voprosy sovremennoj nauki i praktiki, 1 (50), 82-91.

[9] Kumar, P., Sharma, N., Ranjan, R., Kumar, S., Bhat, Z. F., Jeong, D. K. (2013). Perspective of Membrane Technology in Dairy Industry: A Review. Asian Australasian Journal of Animal Sciences, 26 (9), 1347-1358. doi: 10.5713/ajas.2013.13082

[10] Cai, M., Zhao, S., Liang, H. (2010). Mechanisms for the enhancement of ultrafiltration and membrane cleaning bydifferent ultrasonic frequencies. Desalination, 263 (1-3), 133-138. doi: 10.1016/j.desal.2010.06.049

[11] Cheng, T. W., Li, L. N. (2007). Gas-sparging cross-flow ultrafiltration in flat-plate membrane module: Effects of channel height and membrane inclination. Separation and Purification Technology, 55 (1), 50-55. doi: 10.1016/j.seppur.2006.10.026

[12] Lobasenko, B., Semenov, A. G. (2013). Intensification of ultrafiltration concentrating by the separation of the concentration boundary layer. Foods and Raw Materials, 1 (1), 74-81. doi: 10.12737/1560

[13] Ostapchuk, M., Stankevych, G. (2006). Matematychne modelyuvannya na EOM. Odesa: Druk, 313.

[14] Deinychenko, G., Mazniak, Z., Kramarenko, D., Guzenko, V. (2015). Determination of ultrafiltration membranes shrinkage factor. Ukrainian Food Journal, 4 (2), 328-334.

[15] Liu, D. Z., Weeks, M. G., Dunstan, D. E., Martin, G. J. O. (2014). Alterations to the composition of casein micelles and retentate serum during ultrafiltration of skim milk at 10 and $40{ }^{\circ} \mathrm{C}$. International Dairy Journal, 35 (1), 63-69. doi: 10.1016/j.idairyj.2013.10.017

[16] Deynichenko, G., Maznyak, Z., Zolotukhina, I., Gafurov, O. (2011). Membrane concentration of non-fat milk stuff. Recent Journal, 3 (33), 245-248. 